\title{
Roots and relationships of greening buildings
}

\author{
S. Fruehwirth \\ Institute of Architecture and Landscape, Technical University Graz, \\ Austria
}

\begin{abstract}
In ancient Greece, the Hanging Gardens have their origin in the cult of Adonis. To honour Adonis, corn and spices were planted on the roof of the houses - and the Cult Garden emerged. By 2,600 BC it was reported that grapevines were used for arbours. Such functional uses were also found in Roman gardens: pergolas with rambling roses and arbour trails rambling with grapevines already existed. As protection against climatic influences, the grass roofs in Scandinavia and also in the hot southern regions were used to equalise temperature and create a pleasant indoor environment. Nowadays, similar temperature regulation is used in Austria and Hungary for subterranean wine cellars. Further subterranean buildings are military bunkers. They were built underneath artificial earth banks, and for a better camouflage, the roof was cropped. In his "five points of a new architecture", Le Corbusier explained the necessity of roof greenings. This green roof was one of the first claims for a private green space generated with the atmosphere of nature. Looking at the individual origins of the history of covered buildings more closely, we can compare the different but sometimes similar use of plants to greening buildings in connection with contemporary architecture.
\end{abstract}

Keywords: historical development of greening buildings, vertical garden, green facades, green roof.

\section{Introduction}

The historic development of greening buildings has various origins. In this paper, the meaning of the creation of green roofs in ancient times and the first mention of tendrillar plants that are interwoven with a built horizontal and vertical environment will be analysed and recovered in contemporary architectural tendencies. 
The important history of the Adonis garden, planted for a cultic ceremony, as well as the usefulness of a roof garden as mentioned by Le Corbusier, are also part of this observation of green wraps which differ according to their utilisation. Buildings with grass roofs can be a protection against the cold in northern Europe and make for temperature equalisation in southern regions, or they can be edifices for military purposes which need to be hidden and camouflaged; examples of contemporary architecture that merges with the landscape or dissolves within it work with nearly the same motives.

\section{The roots of greening buildings}

\subsection{The cultic garden}

In midsummer, a festival used to be celebrated in Athens in honour of Adonis. The Adonis cult, accruing from Syria, was introduced in Ancient Greece in the $6^{\text {th }}$ century. Women put potsherds filled with soil onto roofs and planted herbs and crops; in the middle of the roof area was a doll that portrayed Adonis. The rapid sprouting of the seeds and their similar rapid fading was evocative of the early death of Adonis and emphasised the transience of the earthly existence. The Adonis garden was also known in Imperial Rome [1]. The previously temporarily decorated roof gardens in Ancient Greece evolved into grand leafy roofs, and similar ones developed in Rome later on where fruit trees and laurels were also planted. In the cities, there was not much space, thus, the flat roofs were planted and used as roof gardens - hence, useful plants could be found nearby.

In any case, the commencement of the culture of roof gardens and pot gardens can be found in the Adonis gardens - they showed the people how they would be able to vegetate the roofs of the middle-class houses and royal villas [2].

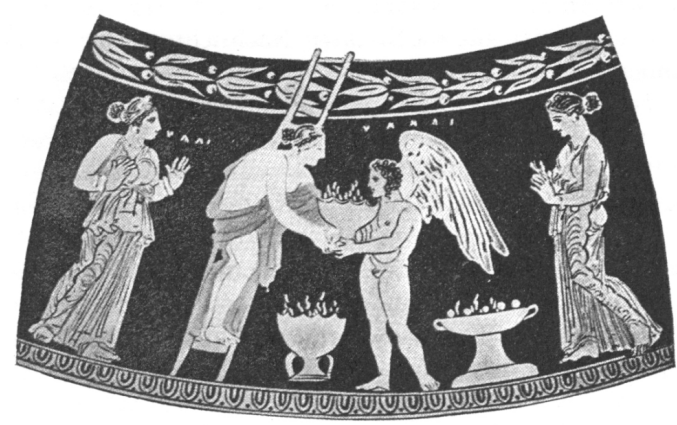

Figure 1: $\quad$ Adonis garden.

\subsection{The sacred garden}

The grave mound or the cairn is one of the oldest building types. Tumuli were built to protect a corpse against animals and also against grave robbers. The development of the grave mounds is shown through the monumental structure of 
the burial chamber and also in augmenting the grave mound itself. The tumulus can be seen as forerunner of the pyramids. It can be assumed that the pyramids had plants on the steps just like their precursors were overgrown [3].

The Egyptian temple complexes were decorated with parks. On the one hand, agreeable surroundings, and on the other an appropriate area due to the symbolism of the flora that was supposed to be created for the Gods.

Apart from this, the revenues of these temple gardens were also an economical factor because oblations, (wine, vegetables, fruits and groceries) were gathered and harvested. The garden's purpose was to secure the deceased's rebirth and his/her living on in a likeable world. It is due to the various components of a garden - lake, fauna and flora - that guarantee his/her continuance through their symbolic character. There were also plants in the interior of the gravesites. The walls of the rock tombs were decorated with paintings of grape harvesting scenes, and widely ramified vine-covered arbours covered the grave [4]. At the excavation of the terrace temple in Deir-el-Bahari, which Queen Hatshepsut had ordered to be built in honour of the Sun God Amun-Ra, two basins on the lower terrace were discovered that had papyrus plants growing on them.

The Romans also preferred aesthetic gardens for their graves, which were located outside of the city walls [5]. They were furnished with grave gardens. Emperor Augustus had himself built a tomb in his lifetime: The Mausoleum in Rome was constructed as circular edifice with a bottom section of white stone in which the burial chamber was located; this bottom section has been preserved up to the present. The tumulus above it was grown over with evergreen trees; later on the Mausoleum was also used as vineyard.

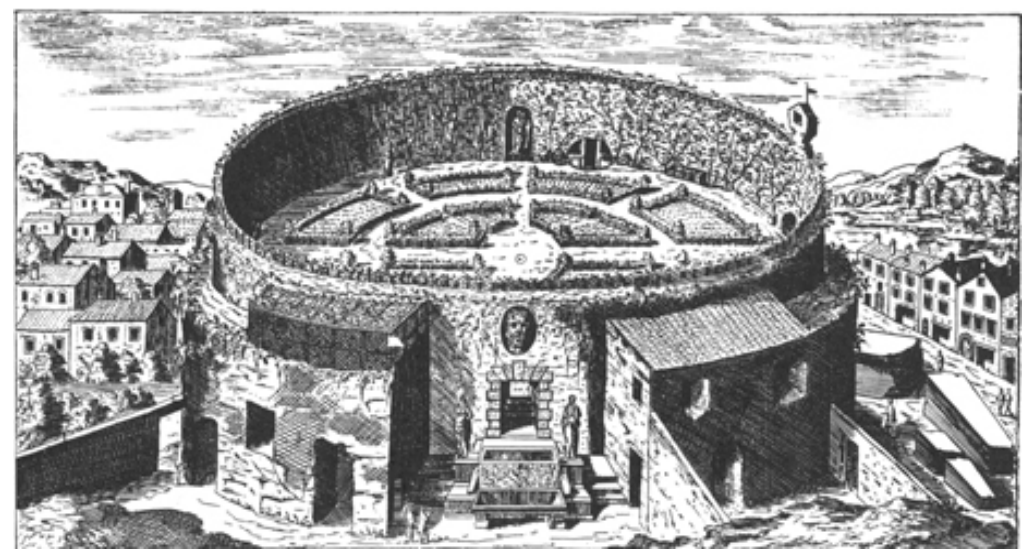

Figure 2: $\quad$ Mausoleum Augustus.

\subsection{Symbolism of nature}

Egypt is the oldest country where depictions of viniculture come from. Already, in the IV and V dynasty, paintings told stories about vines. The grapevines were presumably (partly circularly) cultivated on arbours, later richly painted column 
pergolas evolved hence. Vine arbours remained as a centre point of all gardens up to the New Empire. In Egypt, the god of vegetation, Osiris, was considered as the "master of the wine". The Greek god of wine and of vegetation in general, Dionysios, was attributed a stick swathed with ivy and vines [6]. The evergreen ivy is a symbol for life and immortality, the vine and its fruits are also symbols of life and fertility.

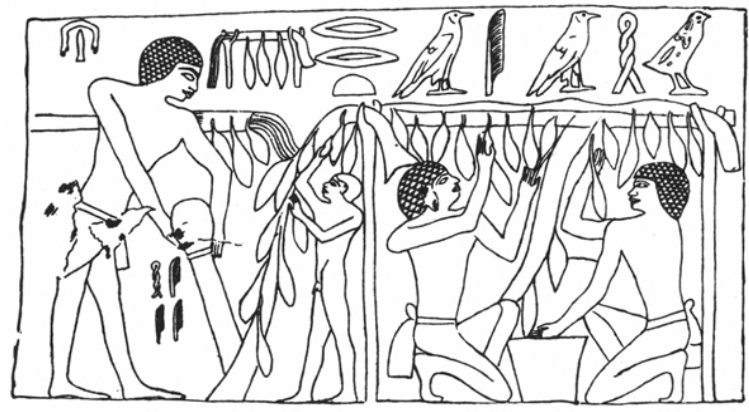

Figure 3: Vine-covered arbour.

The mentioning of arbours in medieval Rome allowed for different forms of usage and interpretation. It was a Jewish-Oriental custom to live in arbours during the harvest in autumn, and these arbours were made of green branches and erected on rooftops, in courtyards, or on places. The arbours, which had already been built by the Egyptians, were either flat or bent and usually cropped with a vine. In the Roman landscape gardening, arbours were intended and designed to be shady and usually full with vines or roses that grew on a vertical tendril of wooden grating.

\subsection{The hanging gardens}

The custom of creating hanging gardens on vault cavities or on rooftops came into existence in the Orient; the much admired magnificence of the so-called hanging gardens of Semiramis cannot clearly be presented in narrations.

The most important stories are told by Diodor and Strabo, who only concur with each other in one point: in the side length of the bottom section which measures 480 metres. Diodor describes the Hanging Gardens "similar to a theatre" [7] that is cropped with tall trees that look like mountains and like a theatre that lies upon a vault in which baronial rooms were established. According to Diodor, the Hanging Gardens were not built by Queen Samiramis, whom the gardens had previously been ascribed to, but by an Assyrian king who had constructed them for one of his wives in order to remind her of her hilly homeland.

A number of writers of the antiquity gave an account of the Hanging Gardens; the depictions and places differ and cannot exactly be proved. Even if, the Hanging Gardens might only have been a fantasy, they still gave an impetus for the spreading of the rooftop garden tradition in a bigger scale [8]. 


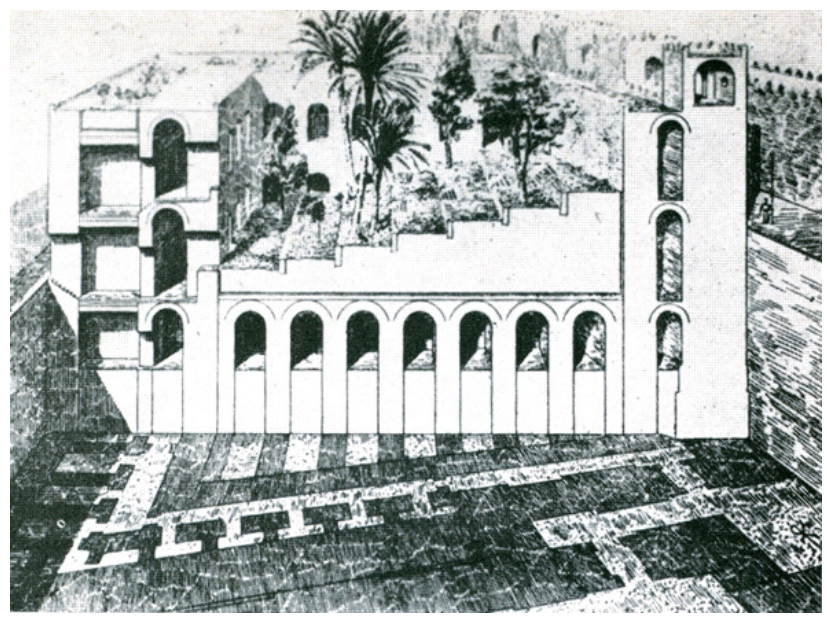

Figure 4: Hanging Garden of Semiramis.

\section{Protection against climatic conditions}

Grass roofs are recognised as a building type in cold climatic areas in northern Europe as well as in hot regions, e.g. in Tanzania. They are very effective as climate modulators. In the first case, they keep the interior room warm, in the latter; they provide cooling of the buildings.

In the traditional turf sod house of Ireland no artificial heating was needed in winter. The roof served as a heat reservoir whose heat insulation functioned very well. That was the reason why the waste heat from the cooking pit and from the inhabitants sufficed in order to keep the room's climate agreeable [9]. Originally, sheep kept the sods short.

The development of the stone houses with grass roofs on the construction came into existence due to lack of wood. The only domestic building materials on the Faroe Islands are grass and stone; wood was imported or collected as driftwood at the coastline.

The grass covered houses fit perfectly into the landscape and offer a good protection against heat and humidity. The construction consists of planking on top of which there is birch bark which keeps off humidity. On top of that lie two coatings of sod, which can be found in the surrounding meadows. This type of grass roof endures about 50 years [10].

The closeness to the seaside, the topography, and the climatic influences are mainly the reason for the form of the arrangement and the construction of the houses. The adjustment to the topography leads to the situation that cellar rooms emerged due to the height compensation, and meadow and roof became one.

An example for grass roofs in hot regions can be found in Tanzania. There are three different types of grass roofs: the Hehe house, the Mbulu house, and the Gogo house. The differences concern the roof pitch and the thickness of the layer of grass. 


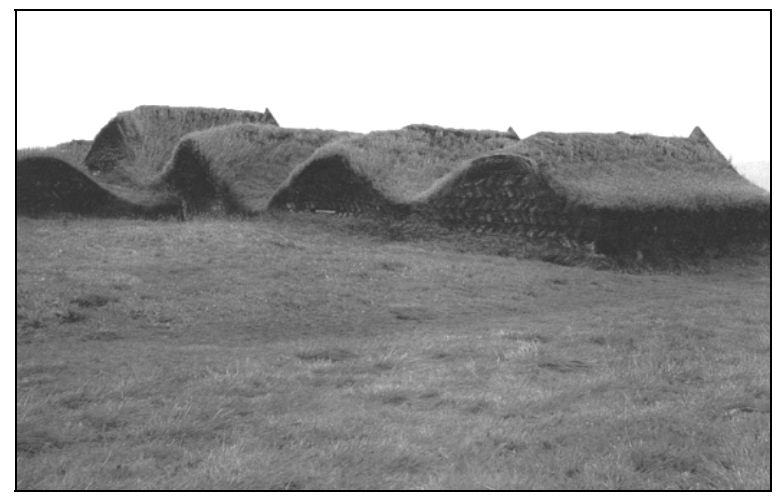

Figure 5: Turf sod house.

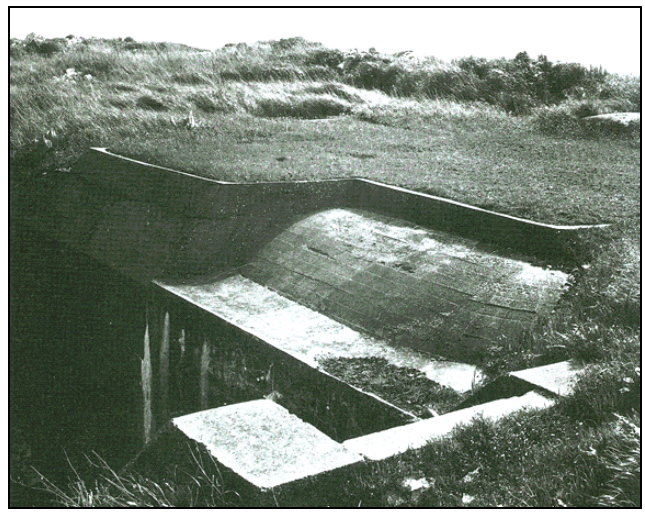

Figure 6: Camouflaged bunker.

The climatic advantages of the grass roofs are also leveraged with wine cellars in Austria and Hungary. The cellars are often covered with a layer of earth in order to have an even-tempered indoor environment on which a natural grass roof develops.

\section{Camouflage}

In war times, bunkers were built for the military underneath artificial earth banks. For better camouflage, they were also covered with grass. Bunkers that were not constructed subterraneously were partly hidden behind plants. Apart from ivy and wild vine, also rosa rugosa was employed. This more often blooming wild rose is very resistant and grows at places where it cannot be nursed. In World War II, it was planted as camouflage for the bunkers and was, thus, also called Adolf-Hitler-rose [11].

Bunkers that had not been camouflaged during the war became a topic in the post-war period. In Germany, the majority of people wanted the bunkers to 
disappear from their sight in order to not be reminded of the terrible doings during the war. To some extent, these eyesores [12] were torn down, which was very expensive and not always possible because some bunkers were built right next to other buildings which, hence, would have been destroyed as well. In the 1980 's, it was begun to camouflage and hide the facades of the bunkers with entwining plants. Bunkers cropped with ivy or Virginia creeper did not interfere with the view of a place.

\section{Manifestos in the $20^{\text {th }}$ century}

Auguste Perret was the first architect who built roof gardens on iron concrete ceilings and developed a style appropriate for the material involved in connection with this new building material. The apartment building in the Rue Franklin in Paris which was conceptualised by him is a frame construction with a discreetly decorated façade and large-scale glazing between the props. The house was completed in 1903 and has roof terraces which are positioned on two levels.

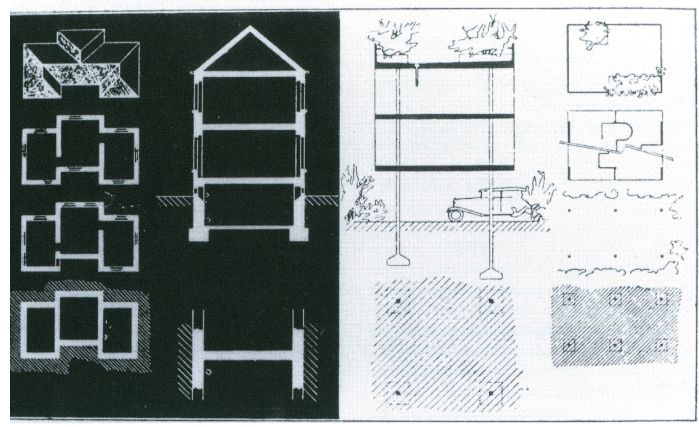

Figure 7: $\quad$ Five points of a new architecture.

\subsection{The usefulness of a roof garden according to Le Corbusier}

Le Corbusier (a student of Auguste Perret) was one of the first systematic builders and theorists of roof greening [13]. In the "Five points towards a new architecture" [14] by Le Corbusier and Pierre Jeanneret from 1926, the importance and the advantages of a roof garden are stressed in point 2:

"The roof gardens: The flat roof requires, first of all, consistent utilisation for living purposes: Roof terrace, roof garden. Furthermore, iron concrete needs to be protected against the changeability of the outside temperature. By maintaining a constant humidity on the roof concrete, it can be avoided that the iron concrete is too much in motion.

The roof terrace complies with both requirements (humid sand stratum, covered with concrete slab, in the joints of the same grasslands; the soil of the flowerbeds with the sand stratum in direct connection). Like this, the rain water runs off extremely slowly; drainpipe inside the house. There remains, thus, a 
latent humidity on the roof membrane. Roof gardens have lush vegetation. Shrubs, even small trees up to a height of 3-4 metres, can easily be planted. By doing this, the roof garden becomes the most favoured place of the house. In general, roof gardens stand for the retrieval of the completely occupied areas."

Le Corbusier talks about the usage of the roof in the form of a roof garden for living purposes and, in this connection, with the protection of the roof structure. Almost 50 years later - in 1973 - Friedensreich Hundertwasser wrote a manifesto in which he expresses his concerns about the environment.

\subsection{Manifesto for the "Tree Leaser Campaign" [15]}

"There is not that much space occupied in the monotone, sterile city. Hence, why should not live a tree instead of a human being in a flat/an apartment when oxygen becomes rare? You only need a window in a flat and a little space behind it. This is very important and can revolutionise the city more than when only the roofs are covered with woods/forests. ... The vertical, sterile walls of the street canyons from whose aggression and tyranny we suffer daily become like green valleys where man can breathe freely.

The tree leaser pays for his/her rent with oxygen through his/her capacity of swallowing dust, as anti-noise machine through producing calmness, through poison obliteration, through purification of the contaminated rain water, as producer of happiness and health, as bringer of butterflies, through beauty, and through many other currencies." [16]

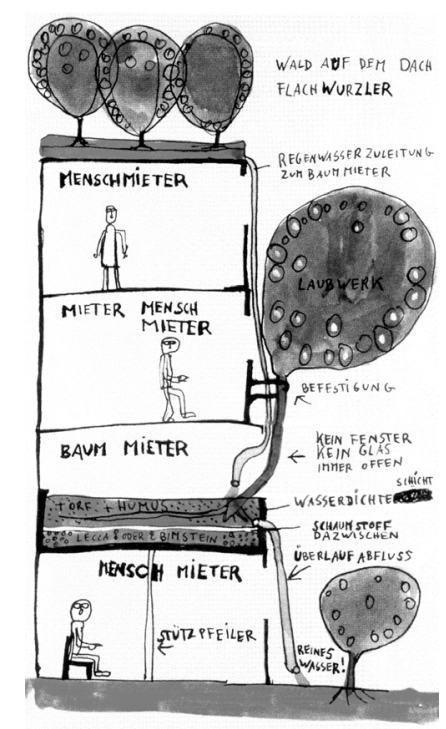

Figure 8: $\quad$ Tree Leaser Campaign, Hundertwasser. 
The topics that agitate Friedensreich Hundertwasser are still the same today and frequently discussed: trees and green in the city provide oxygen, swallow dust, have advantages for the urban water supply, serve as noise protection and see to an agreeable climate.

\section{The melting of architecture and landscape}

Different motives can be found in contemporary examples of planting vegetation on buildings.

\subsection{Architecture that resolves itself into the topography}

In the picturesque landscape of South Tyrol the winery Manincor was built under the earth, hidden under the vineyard. It is not only the cool climate, we know from traditional wine cellar buildings, which is favourable, the main conception of the architects W. Angonese, R. Köberl and S. Boday was to leave the landscape untouched and to use the maximum of subterranean resources.

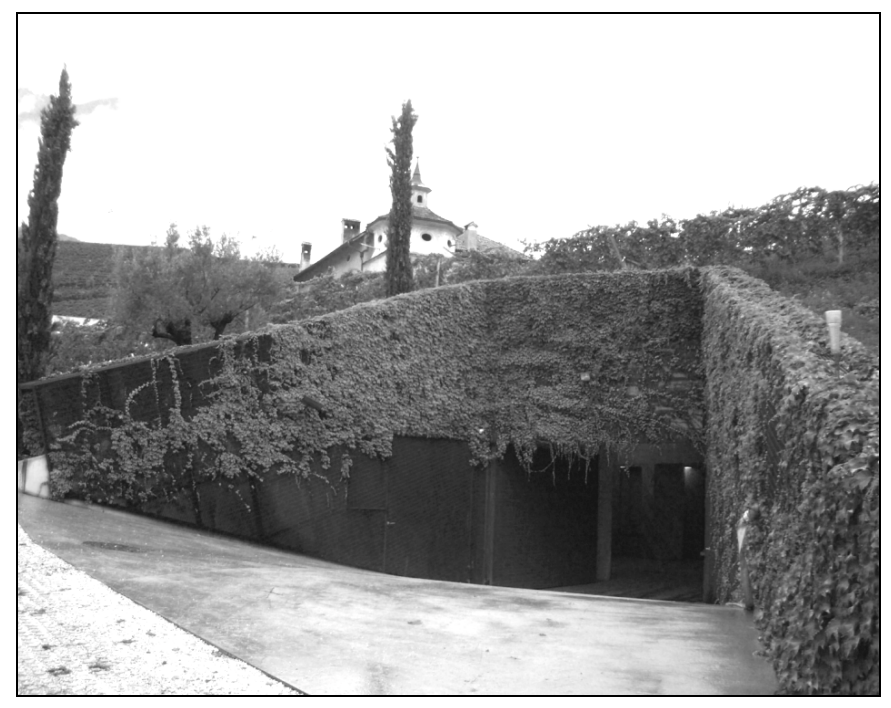

Figure 9: $\quad$ Winery Manincor, Caldaro, Italy, 2004.

\subsection{Camouflaged or hidden architecture in the landscape}

The holiday homes designed by E. Francois and D. Lewis designed a facade made of trees and hedges. The sense is not to camouflage the buildings in terms of invisibility, the camouflage works like an integrative element. The surrounding of the site was taken as a part of the design components, so the trees and hedges build the facade. The lively cover is designed for the course of a year and the growing of the plants and completes the architecture. 


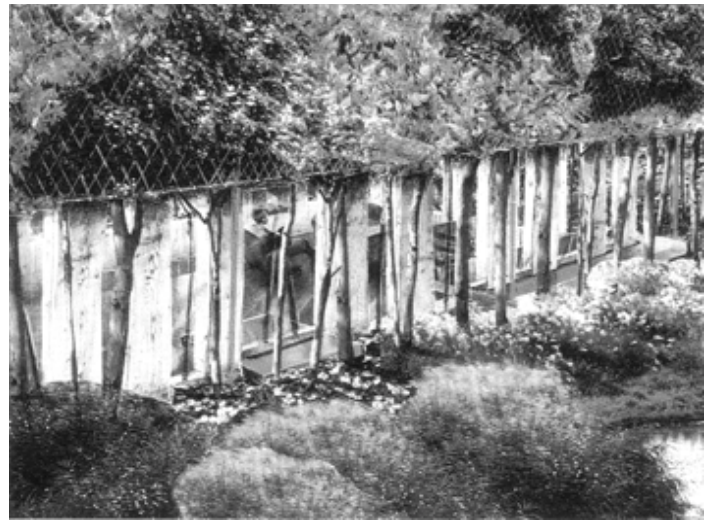

Figure 10: $\quad$ Summer Cottages, Jupilles, France, 1998.

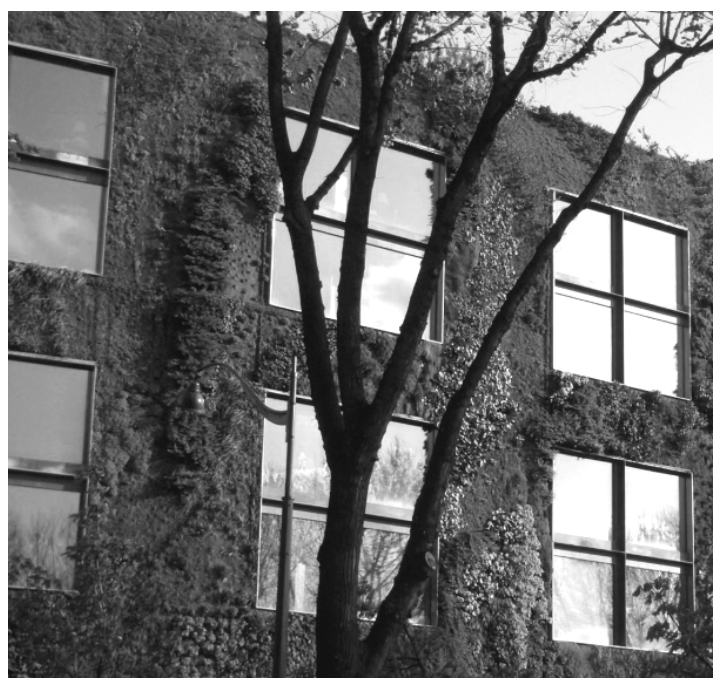

Figure 11: $\quad$ Musee du Quai Branly, Paris, France, 2006.

\subsection{The vertical garden}

The green wall of the Musee du Quai Branly ist a result of the teamwork of the architect Jean Nouvel and the botanist Patrick Blanc. The main intention of this design is to bring green into the grey urban space for an equalisation of sealed areas according to an ecological point of view. The vertical garden, covered with moss and fern, implies an additional value to the aesthetics of the urban surroundings. 


\section{Summary}

In contemporary architectural examples of greening buildings have different meanings: architecture uses green wraps as aesthetic facades similar to the tradition in ancient Rome where access arbours were decorated with roses. The dissolving of contemporary architecture into a landscape or the merging of buildings and landscape can also be found as motive for military bunkers that are hidden in the territory and used the green cover as camouflage. The meaning of greening buildings shifted from a cultic, sacred or symbolic content to an ecological and aesthetic point of view. Contemporary greening buildings are significant examples of a dualistic immersion from architecture and landscape.

\section{References}

[1] Gothein, M. L. (1994). Geschichte der Gartenkunst 1 Von Ägypten bis zur Renaissance in Italien, Spanien und Portugal. München, Diederichs. S. 63

[2] Ahrendt, J. (2007). Historische Gründächer: Ihr Entwicklungsgang bis zur Erfindung des Eisenbetons, Dissertation TU Berlin. S. 28

[3] Ahrendt, J. (2007). Historische Gründächer: Ihr Entwicklungsgang bis zur Erfindung des Eisenbetons, Dissertation TU Berlin. S. 8

[4] Hugonot J.-C. Ägyptische Gärten. In: Carroll-Spillecke, M. and L. Brubaker (1992). Der Garten von der Antike bis zum Mittelalter. Mainz am Rhein, von Zabern. S. 39-40

[5] Jashemski W. F. Antike römische Gärten in Campanien. In: CarrollSpillecke, M. and Brubaker, L. (1992). Der Garten von der Antike bis zum Mittelalter. Mainz am Rhein, von Zabern. S. 201

[6] Lurker, M. (1991). Wörterbuch der Symbolik. Stuttgart, Kröner. S. 822

[7] Diodor zit. bei Gothein, M. L. (1994). Geschichte der Gartenkunst 1 Von Ägypten bis zur Renaissance in Italien, Spanien und Portugal. München, Diederichs. S. 35

[8] Ahrendt, J. (2007). Historische Gründächer: Ihr Entwicklungsgang bis zur Erfindung des Eisenbetons, Dissertation TU Berlin. S. 24

[9] Minke, G., Witter, G., et al. (1983). Häuser mit grünem Pelz: ein Handbuch zur Hausbegrünung. Frankfurt/Main, Fricke. S. 29

[10] Jessen, C. Das Traditionelle Haus der Färöer Inseln - Ein Beispiel für archetypische Grasdächer in: Detail, Jg. (1996) Nr.5 S.660-665

[11] http://www.ostseegebiet.de/Kartoffelrose.181.0.html, 21.02.2008

[12] Foedrowitz, M. (1998). Bunkerwelten: Luftschutzanlagen in Norddeutschland. Berlin, Links. 180

[13] Ahrendt, J. (2007). Historische Gründächer: Ihr Entwicklungsgang bis zur Erfindung des Eisenbetons, Dissertation TU Berlin. S.132

[14] Le Corbusier / Jeanneret, P. Fünf Punkte zu einer neuen Architektur. In: Conrads, U. (1994). Programme und Manifeste zur Architektur des 20. Jahrhunderts. Braunschweig Vieweg. 
68 Eco-Architecture II

[15] Via Manzoni, Mailand, 1973 Hundertwasser takes part at the Triennale di Milano, where 12 "Tree Leaser" were planted through the window in the Via Manzoni

[16] Harry Brand. Hg., Hundertwasser, Köln, 1993, S. 149. Zitiert in: DAIDALOS, (1999), Nr.73. S.26-35 